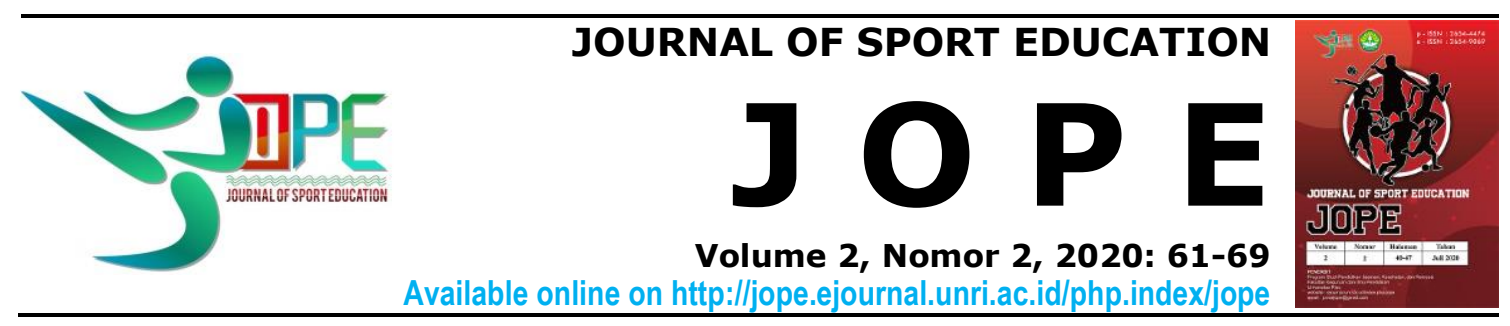

\title{
Penerapan model pembelajaran jigsaw untuk meningkatkan motivasi dan hasil belajar mahasiswa penjas pada mata kuliah filsafat penjas dan olahraga
}

\author{
Yahya Eko Nopiyanto ${ }^{1}$, Septian Raibowo ${ }^{2}$ \\ ${ }^{1,2}$ Universitas Bengkulu \\ yahyaekonopiyanto@unib.ac.id ${ }^{1}$, septianraibowo@unib.ac.id ${ }^{2}$
}

Received: 22 Mei 2020; Revised: 3 June 2020; Accepted: 5 June 2020

doi http://dx.doi.org/10.31258/jope.2.2.61-69

\begin{abstract}
Abstrak
Tujuan dari penelitian ini adalah untuk mengetahui penerapan model pembelajaran jigsaw dalam meningkatkan hasil belajar mahasiswa penjas pada mata kuliah filsafat penjas dan olahraga. Metode penelitian yang digunakan adalah tindakan kelas, yang terdiri dari empat tahapan yaitu, perencanaa, tindakan, observasi, dan refleksi. Subjek penelitian ini adalah mahasiswa penjas yang mengikuti perkuliahan filsafat penjas dan olahraga, dengan jumlah 45 mahasiswa. Teknik dan instrumen pengumpulan data menggunakan observasi, kuesioner, dan tes tertulis. Analisis data yang digunakan adalah deskriptif kualitatif. Berdasarkan hasil tindakan pada siklus 1 dapat diketahui bahwa 55\% mahasiswa memiliki motivasi belajar dalam ketegori baik, nilai rata-rata kelas sebesar 68, ketuntasan belajar 68\%. Pada siklus 2 diketahui bahwa $80 \%$ mahasiswa memiliki motivasi belajar dalam kategori baik sekali, nilai rata-rata kelas sebesar 78, ketuntasan belajar $85 \%$. Berdasarkan hasil penelitian ini dapat disimpulkan bahwa penerapan model pembelajaran jigsaw dapat meningkatkan motivasi dan hasil belajar mahasiswa penjas pada mata kuliah filsafat penjas dan olahraga.
\end{abstract}

Kata Kunci: pembelajaran, jigsaw, penjas, filsafat

\section{Application of jigsaw learning model to improve the learning outcomes of physical education students in physical education and sports philosophy course}

\begin{abstract}
This research was aimed to investigate the application of jigsaw learning model in improving the learning outcomes of physical education students in physical education and sports philosophy course. The research method using classroom action research, which consists of planning, action, observation, and reflection. The subjects consisted of 45 students. The data were collected using observation, questionnaire, test and analyzed using deskriptif kualitatif. The results of the action in cycle 1 showed that 55\% of students have good motivation, the average grade 68, completeness of learning 68\%. The results of the action in cycle 2 showed that $80 \%$ of students have very good motivation, the average grade 78 , completeness of learning $85 \%$. Based on the results of this research, it can be concluded that the application of the jigsaw learning model improved the motivation and learning outcomes of physical education students on physical education and sports philosophy courses.
\end{abstract}

Keywords: learning, jigsaw, physical education, philosophy

How To Cite: Nopiyanto, Yahya Eko \& Raibowo, Septian. (2020). Penerapan model pembelajaran jigsaw untuk meningkatkan motivasi dan hasil belajar mahasiswa penjas pada mata kuliah filsafat penjas dan olahraga. Journal of Sport Education (JOPE), 2 (2), 61-69. 
Journal of Sport Education (JOPE), 2 (2) 2020 - 62

Yahya Eko Nopiyanto ${ }^{1}$, Septian Raibowo ${ }^{2}$

\section{PENDAHULUAN}

Mata kuliah filsafat penjas dan olahraga merupakan salah satu pilihan wajib bagi mahasiswa penjas di Universitas Bengkulu. Sebagian besar mahasiswa kurang termotivasi untuk belajar filsafat penjas dan olahraga karena dirasa sangat membosankan. Rasa bosan tersebut dapat timbul dikarena olah banyak faktor diantaranya adalah adanya dominasi oleh dosen dalam proses pembelajaran (teacher center) dan penggunaan model pembelajaran yang belum tepat dilakukan oleh dosen pengampu mata kuliah. Rasa bosan yang terus berkembang dalam diri mahasiswa dapat mempengaruhi motivasi dan hasil belajar. Untuk itu perlu dilakukan upaya perbaikan dalam proses pembelajaran sehingga mampu meningkatkan motivasi dan hasil belajar mahasiswa. Salah satu model pembelajaran yang dapat diterapkan oleh dosen untuk meningkatkan minat dan hasil belajar mahasiswa adalah model pembelajaran jigsaw.

Model pembelajaran jigsaw merupakan model pembelajaran yang mampu memfasilitasi mahasiswa untuk berpikir secara aktif, kreatif, dan inovatif dalam proses pembelajaran. Model pembelajaran ini tidak hanya mengembangkan kemampuan intelektual mahasiswa tetapi seluruh potensi yang ada, termasuk pengembangan emosional dan pengembangan keterampilan. Dengan menerapkan model pembelajaran ini akan melatih mahasiswa berani mengemukaan pendapat, mengembangkan diri, bekerja sama dan bertanggungjawab secara individu, saling ketergantungan positif, interaksi personal dan proses kelompok. Penggunaan model pembelajaran ini secara efektif dan efisien akan mengurangi dominasi dosen dalam proses pembelajaran, sehingga tingkat kebosanan mahasiswa dalam menerima pelajaran akan berkurang (Lie, 2010).

Berdasarkan hasil penelitian dapat diketahui bahwa penerapan model pembelajaran kooperatif jigsaw dapat meningkatkan motivasi belajar dan hasil belajar (Tsay \& Brady, 2010). Hasil penelitian yang lain juga menyatakan bahwa model pembelajaraan kooperatif jigsaw dapat meningkatkan motivasi mahasiswa, hasil belajar mahasiswa dan lebih efektif untuk diterapkan dalam proses pembelajaran dibandingkan dengan metode pembelajaran konvensional (Budiawan, 2013). Model pembelajaran kooperatif jigsaw dapat meningkatkan aktivitas belajar dan hasil belajar mahasiswa dari $73 \%$ pada siklus 1 menjadi 87,5\% (Thomas \& Setiaji, 2014).

Berdasarkan hasil pengamatan selama mengampu mata kuliah filsafat penjas dan olahraga dapat diketahui bahwa: a) $70 \%$ mahasiswa dalam mengikuti perkuliahan bersifat pasif dan mencatat saja, b) $80 \%$ mahasiswa dalam mengikuti pembelajaran mempunyai motivasi kurang, hal ini dapat dilihat ketika dosen selesai menerangkan dan kesempatan bertanya atau mengemukakan pendapat, hanya dua orang saja yang memanfaatkan kesempatan tersebut dan orangnya tetap sama c) sebagian besar mahasiswa tidak dapat membahas tugas mandiri yang diberikan 
Journal of Sport Education (JOPE), 2 (2) 2020 - 63

Yahya Eko Nopiyanto ${ }^{1}$, Septian Raibowo ${ }^{2}$

oleh dosen dan mengumpulkan tugas tersebut tidak tepat pada waktunya, d) minat mahasiswa dalam mengikuti pembelajaran tergolong rendah karena $80 \%$ mahasiswa asik bermain handphone saat proses pembelajaran sedang berlangsung, e) masih ada hasil belajar mahasiswa yang belum tuntas karena kurangnya motivasi belajar.

Motivasi belajar adalah serangkaian daya penggerak dalam diri seseorang yang menimbulkan kegiatan belajar dan memberikan arah pada kegiatan belajar, sehingga tujuan yang dikehendaki oleh subjek belajar itu dapat tercapai (Sardiman, 2012). Sedangkan hasil belajar merupakan perubahan-perubahan yang terjadi pada diri mahasiswa baik yang menyangkut aspek kognitif, afektif, dan psikomotor sebagai hasil dari kegiatan belajar (Susanto, 2015).

Hasil belajar yang dimaksud dalam penelitian ini adalah perubahan mahasiswa dalam aspek kognitif dan afektif setelah mengikuti pembelajaran filsafat penjas dan olahraga.

Berdasarkan permasalahan yang terjadi pada proses pembelajaran filsafat penjas dan olahraga, maka diperlukan langkah konkrit untuk memperbaiki kondisi tersebut. Sepengetahuan penulis, hingga saat ini belum pernah dilakukan penelitian tentang penerapan model pembelajaran jigsaw untuk meningkatkan hasil belajar filsafat penjas dan olahraga di prodi penjas Universitas Bengkulu. Hal inilah yang menjadi motivasi penulis untuk melakukan penelitian dengan judul "penerapan model pembelajaran jigsaw untuk meningkatkan hasil belajar mahasiswa penjas pada pada mata kuliah filsafat penjas dan olahraga".

\section{METODE}

Metode penelitian ini adalah tindakan kelas yang berfokus untuk meningkatkan hasil belajar mahasiswa pada mata kuliah filsafat penjas dan olahraga. Subjek dalam penelitian ini adalah mahasiswa penjas Universitas Bengkulu, yang mengikuti perkuliahan filsafat penjas dan olahraga dengan jumlah 45 mahasiswa. Prosedur penelitian yang digunakan dalam penelitian ini terdiri dari perencanaan, pelaksanaan tindakan, observasi, dan refleksi.

\section{Perencanaan}

a. Menelaah materi pembelajaran filsafat penjas dan olahraga beserta indikatornya.

b. Menyusun RPS sesuai indikator melalui model pembelajaran jigsaw.

c. Menyiapkan sumber belajar, lembar observasi, kuesioner, dan tes tertulis.

\section{Pelaksanaan Tindakan}

Pelaksanaan tindakan menggunakan model pembelajaran jigsaw untuk meningkatkan hasil belajar filsafat penjas dan olahraga. Dalam pelaksanaan penelitian ini terdiri dari 2 siklus, masing-masing 3 pertemuan tiap siklusnya dengan skenario pembelajaran sebagai berikut:

a. Menjelaskan kepada mahasiswa tentang petunjuk pelaksanaan pembelajaran dengan model pembelajaran jigsaw.

b. Membagi mahasiswa ke dalam beberapa kelompok, yang masingmasing kelompok terdapat satu orang 
Journal of Sport Education (JOPE), 2 (2) 2020 - 64

Yahya Eko Nopiyanto ${ }^{1}$, Septian Raibowo ${ }^{2}$

ahli yang akan menjelaskan materi

kepada teman sekelompoknya. Satu

kelompok ahli dan beberapa

kelompok asal.

c. Berdiskusi dengan kelompok ahli tentang materi pembelajaran, selanjutnya kelompok ahli menjelaskan kepada anggota kelompok asal.

\section{Observasi}

Pada saat mahasiswa melakukan diskusi dengan menerapkan model pembelajaran jigsaw, peneliti merekam dan mengamati setiap respons mahasiswa dalam proses pembelajaran. Tahap observasi dilakukan oleh peneliti untuk mengamati setiap kejadian selama pelaksanaan tindakan menggunakan model pembelajaran jigsaw. Kegiatan observasi dilaksanakan dengan menggunakan lembar observasi untuk mengetahui peningkatan motivasi dan hasil belajar filsafat penjas dan olahraga.

\section{Refleksi}

Pada tahap ini, peneliti melakukan beberapa proses dalam pencapaian tahapan refleksi, yaitu:

a. Analisis Data

Setelah data yang direkam melalui alat audiovisual diputar kembali, maka peneliti melakukan diskusi dengan rekan sejawat yang melakukan kolaborasi tentang hasil yang sudah didapat. Diskusi meliputi keberhasilan, kegagalan dan hambatan yang dijumpai pada saat melakukan tindakan.

b. Mereduksi data
Data yang diperoleh selanjutnya dipilih yang benar-benar dibutuhkan dan dapat dijadikan acuan dalam menyusun laporan hasil penelitian.

c. Menyusun langkah perbaikan

Setelah mendapatkan gambaran tentang permasalahan dan hambatan yang ditemukan, maka langkah selanjutnya peneliti menyusun kembali rencana kegiatan yang mengacu pada kekurangan yang belum didapat, sehinggga dapat memperoleh hasil yang baik pada siklus ke2.

Teknik dan Instrumen Pengumpulan Data

Teknik dan instrumen pengumpulan data yang digunakan dalam penelitian tindakan kelas ini adalah observasi, kuesioner, dan tes tertulis. Panduan observasi untuk mengamati proses motivasi belajar terdiri dari lima indikator (tabel 1). Kuesioner untuk mengukur motivasi belajar mahasiswa terdiri dari 20 item pernyataan yang terdiri dari lima alternatif jawaban (tabel 2). Item pernyataan yang terdapat dalam kuesioner, masing-masing memiliki lima alternatif pilihan selalu, sering, kadang-kadang, sangat jarang, tidak pernah. Setiap jawaban memiliki penilaian mulai dari sangat positif hingga sangat negatif. Kuesioner disusun sendiri oleh peneliti dengan tahapan yaitu; membuat kisi-kisi kuesioner, menyusun butir pernyataan, validasi ahli, uji coba instrumen, revisi dan finalisasi kuesioner. 
Journal of Sport Education (JOPE), 2 (2) 2020 - 65

Yahya Eko Nopiyanto ${ }^{1}$, Septian Raibowo ${ }^{2}$

Tabel 1. Panduan Observasi Motivasi Belajar Mahasiswa

\begin{tabular}{lllc}
\hline Indikator & \multicolumn{1}{c}{ Kriteria penilaian } & Ya & Tidak \\
\hline Tekun dalam belajar & $\begin{array}{l}\text { Mahasiswa menunjukkan sikap tekun dalam } \\
\text { belajar }\end{array}$ & \\
\hline Ulet menghadapi & $\begin{array}{l}\text { Mahasiswa menunjukkan sikap pantang } \\
\text { menyerah dalam menghadapi kesulitan belajar }\end{array}$ & \\
kesulitan & $\begin{array}{l}\text { Mahasiswa memperhatikan penjelasan teman } \\
\text { kelompok dan dosen pengampu kuliah }\end{array}$ & \\
\hline Perhatian dalam & Mahasiswa mendapatkan hasil belajar yang & \\
belajar & baik & \\
\hline Berprestasi dalam & & \\
belajar & &
\end{tabular}

Tabel. 2 Kisi-kisi Motivasi Belajar Mahasiswa

\begin{tabular}{lll}
\hline Variabel & Indikator & No Pernyataan \\
\hline Motivasi Belajar & Tekun dalam belajar & $1,2,3,4,5$ \\
\cline { 2 - 3 } & Ulet dalam menghadapi kesulitan & $6,7,8,9,10$ \\
\cline { 2 - 3 } & Perhatian dalam belajar & $11,12,13,14,15$ \\
\cline { 2 - 3 } & Berprestasi dalam belajar & $16,17,18,19,20$ \\
\hline
\end{tabular}

Tabel 3. Kriteria Peningkatan Motivasi Belajar

\begin{tabular}{cc}
\hline Rentang Nilai & Kriteria \\
\hline $86-100$ & Baik sekali \\
\hline $70-85$ & Baik \\
\hline $60-69$ & Cukup \\
\hline $50-59$ & Kurang \\
\hline $0-49$ & Kurang sekali \\
\hline
\end{tabular}

Tabel 4. Tingkat Keberhasilan Belajar Mahasiswa

\begin{tabular}{cc}
\hline Tingkat keberhasilan & Kategori \\
\hline $86-100$ & Sangat tinggi \\
\hline $70-85$ & Tinggi \\
\hline $60-69$ & Sedang \\
\hline $50-59$ & Rendah \\
\hline $0-49$ & Sangat rendah \\
\hline
\end{tabular}

\section{Analisis Data}

Penelitian ini menggunakan teknik analisis data deskriptif kualitatif. Analisis data dimulai sejak awal sampai akhir pengumpulan data. Data yang terbentuk kata-kata atau kalimat dari hasil observasi diolah menjadi kalimat yang bermakna dan dianalisis secara kualitatif. Analisis data ini kemudian dilakukan setelah penelitian selesai. Data yang diperoleh dari penelitian ini juga berbentuk data deskriptif kuantitatif yang berupa angka sederhana yang diperoleh dari hasil perhitungan lembar observasi pada saat tindakan dilakukan dan disajikan dalam bentuk terstruktur sehingga mudah dipahami.

1. Menghitung Nilai Rerata Motivasi Mahasiswa $\bar{X}=\frac{\sum X}{\sum N}$

Keterangan

$\bar{X}=$ nilai rerata yang dicari

$\sum \mathrm{X}=$ jumlah skor angket semua mahasiswa

$\sum \mathrm{N}=$ jumlah mahasiswa

Hasil perhitungan motivasi mahasiswa dikelompokkan ke dalam lima kategori, lihat pada 
tabel 3.

Yahya Eko Nopiyanto ${ }^{1}$, Septian Raibowo ${ }^{2}$
2. Menghitung mean atau rerata hasil belajar mahasiswa

Nilai rata-rata didapatkan dengan rumus sebagai berikut:

$\bar{X}=\frac{\sum X}{\sum N}$

Keterangan:

$\bar{X}=$ nilai rerata yang dicari

$\sum X=$ jumlah nilai semua mahasiswa

$\sum \mathrm{N}=$ jumlah mahasiswa

3. Menghitung ketuntasan klasikal dengan rumus jumlah mahasiswa yang tuntas dibagi jumlah mahasiswa dikalikan $100 \%$.

\section{Indikator Keberhasilan}

Indikator keberhasilan untuk mengukur peningkatan motivasi dan hasil belajar mahasiswa melalui model pembelajaran jigsaw pada mahasiswa penjas adalah sebagai berikut:

1. Minimal $75 \%$ motivasi belajar mahasiswa penjas dalam mengikuti pembelajaran filsafat penjas dan olahraga melalui model pembelajaran jigsaw meningkat dengan kategori sekurang-kurangnya baik.

2. Minimal $75 \%$ mahasiswa mengalami ketuntasan hasil belajar individual sebesar lebih dari 75 dalam pembelajaran filsafat penjas dan olahraga.

\section{HASIL DAN PEMBAHASAN}

\section{Hasil}

\section{Deskripsi Data Pra-siklus}

Berdasarkan hasil pra-siklus diketahui bahwa hasil belajar mahasiswa penjas Universitas Bengkulu semester II memiliki nilai terendah 20, nilai tertinggi 10 , dan nilai rata-rata 70 . Jumlah mahasiswa yang mendapatkan nilai kurang dari 75 sebanyak 30 mahasiwa, sedangkan yang tuntas hanya 15 mahasiswa. Motivasi belajar mahasiswa mempunyai skor 55 dalam ketegori kurang. Dari data ini, maka motivasi belajar dan hasil belajar mahasiswa penjas pada mata kuliah filsafat penjas dan olahraga harus ditingkatkan.

Tabel 5. Data Pra-siklus

\begin{tabular}{cc}
\hline Indikator & Pra-Siklus \\
\hline Nilai tertinggi & 75 \\
\hline Nilai terendah & 40 \\
\hline Motivasi & 55 \\
\hline
\end{tabular}

\section{Deskripsi Data Tindakan Siklus 1}

Tindakan pada siklus 1 dilaksanakan selama tiga pertemuan. Pada siklus 1, mahasiswa dibagi dalam 9 kelompok asal dengan anggota 5 mahasiswa. Materi pembelajaran pada siklus 1 adalah 1) pengantar filsafat pendidikan jasmani dan olahraga, 2) jenis-jenis filsafat, 3) aliran filsafat dan pengaruhnya dalam pembelajaran pendidikan jasmani dan olahraga. Selanjutnya ketua kelompok asal menerima lembar kerja siklus 1 dan membagi kepada anggotanya. Anggota kelompok yang mendapatkan nilai tertinggi memisahkan diri lalu membentuk kelompok baru yang dsebut dengan kelompok ahli. Kelompok ahli melaksanakan diskusi selama 30 menit lalu 
Journal of Sport Education (JOPE), 2 (2) 2020 - 67

Yahya Eko Nopiyanto ${ }^{1}$, Septian Raibowo ${ }^{2}$

kembali kepada kelompok asal untuk saling dalam proses pembelajaran menggunakan berbagi dengan anggota kelompok lainnya. model pembelajaran jigsaw, hal ini Diskusi dalam kelompok asal berlangsung dikarenakan pengalaman yang pertama bagi selama 30 menit. Kemudian kelompok ahli menyiapkan dan merangkum konsep materi pembelajaran pada siklus 1 untuk dipresentasikan di kelas.

Berdasarkan pengamatan pada siklus 1 dapat mahasiswa. Motivasi belajar mahasiswa pada siklus 1 menunjukkan bahwa $55 \% \quad(25$ diketahui bahwa mahasiswa cukup antusias mahasiswa) memiliki motivasi belajar dalam kategori baik. Nilai rata-rata kelas sebesar 68, mahasiswa yang tuntas belajar sebesar $68 \%$ (31 mahasiswa).

Tabel 6. Data Siklus 1

\begin{tabular}{ccc}
\hline Indikator & Siklus 1 & Kriteria Ketuntasan \\
\hline Motivasi & $55 \%$ & $75 \%$ \\
\hline Ketuntasan belajar & $68 \%$ & $75 \%$ \\
\hline
\end{tabular}

Berdasarkan tabel 6 dapat diketahui bahwa pada siklus 1 belum tercapai kriteria ketuntasan yang telah ditetapkan. Untuk itu perlu dilakukan perbaikan untuk dapat mencapai kriteria ketuntasan pada siklus 2.

\section{Deskripsi Data Tindakan Siklus 2}

Tindakan pada siklus 2 dilaksanakan selama tiga pertemuan. Pada siklus 2 kelompok ahli adalah kelompok yang sama dengan siklus 1 . Hal ini dimaksudkan untuk efisiensi waktu dan memudahkan adaptasi kepada kelompok ahli terhadap model pembelajaran jigsaw. Pada siklus 2, mahasiswa langsung bergabung pada kelompok ahli dengan maksud untuk memberikan waktu yang cukup dalam pembahasan materi pembelajaran. Materi yang disajikan pada siklus 2 adalah 1) konsep dasar bermain, 2) konsep olahraga, 3) perkembangan olahraga di sekolah dan masyarakat. Kelompok ahli melaksanakan diskusi selama 30 menit lalu kembali kepada kelompok asal untuk saling berbagi dengan anggota kelompok lainnya. Diskusi dalam kelompok asal berlangsung selama 30 menit. Kemudian kelompok ahli menyiapkan dan merangkum konsep materi pembelajaran pada siklus 2 untuk dipresentasikan di kelas.

Kekurangan pada siklus 1 sebelumnya adalah mahasiswa masih belum percaya diri dalam menyampaiakan materi pembelajaran dan diskusi belum berjalan secara maksismal. Namun, hak tersebut menjadi lebih baik pada siklus 2. Berdasarkan pengamatan pada siklus 2 dapat diketahui bahwa mahasiswa lebih antusias dalam proses pembelajaran menggunakan model pembelajaran jigsaw, mahasiswa menjadi lebih percaya diri dalam menyampaikan materi pembelajaran, dan diskusi berjalan maksimal. Hal ini dikarenakan mahasiswa mulai terbiasa dengan model pembelajaran jigsaw. Motivasi belajar mahasiswa pada siklus 2 menunjukkan bahwa 80\% (36 mahasiswa) memiliki motivasi belajar baik sekali. Nilai rata-rata kelas sebesar 78, mahasiswa yang tuntas belajar sebesar $85 \%$ (39 mahasiswa). 
Journal of Sport Education (JOPE), 2 (2) 2020 - 68

Yahya Eko Nopiyanto ${ }^{1}$, Septian Raibowo ${ }^{2}$

Tabel 7. Data Siklus 2

\begin{tabular}{ccc}
\hline Indikator & Siklus 2 & Kriteria Ketuntasan \\
\hline Motivasi & $80 \%$ & $75 \%$ \\
\hline Ketuntasan belajar & $85 \%$ & $75 \%$ \\
\hline
\end{tabular}

Berdasarkan pada tabel 7 dapat diketahui bahwa pada siklus 2 telah tercapai kriteria ketuntasan yang telah ditetapkan sebelumnya.

\section{Pembahasan}

Berdasarkan analisis data dapat diketahui bahwa model pembelajaran jigsaw mampu meningkatkan motivasi belajar dan hasil belajar mahasiswa penjas pada mata kuliah filsafat penjas dan olahraga. Hasil penelitian ini didukung oleh hasil penlitian sebelumnya yang menyatakan bahwa model pembelajaran kooperatif mempunyai dampak yang signifikan dan positif terhadap prestasi belajar mahasiswa (Gull \& Shehzad, 2015). Melalui model pembelajaran jigsaw mahasiswa terlibat langsung dan aktif dalam kegiatan belajar mengajar sehingga kemandirian belajar dan motivasi belajar mahasiswa meningkat. Hasil penelitian yang lain juga menyatakan bahwa model pembelajaran jigsaw dapat meningkatkan keterampilan belajar (Hossain \& Tarmizi, 2013). Penerapan model pembelajaran kooperatif tidak hanya mampu meningkatkan hasil belajar mahasiswa tetapi juga dapat meningkatkan nilai kerjasama, keterampilan sosial dan personal (Altun, 2015).

Peningkatan motivasi dan hasil belajar mahasiswa dalam penelitian ini dikarenakan dengan adanya kelompok ahli maka membuat mahasiswa lebih mudah belajar dengan teman sejawatnya yang berperan sebagai ahli. Pada dasarnya mahasiswa lebih nyaman dengan penjelasan dari teman sejawatnya. Dengan model pembelajaran jigsaw mahasiswa mampu bekerjasama dan saing ketergantung secara positif untuk melaksakan pembelajaran sesuai dengan instruksi dari dosen pengampu mata kuliah. Dengan adanya kerjasama antar mahasiswa dalam kelompok maka dapat mencapai tujuan belajar secara bersama. Selain itu, meningkatnya motivasi dan hasil belajar mahasiswa dengan menggunakan model pembelajaran jigsaw dikarena dosen mampu merumuskan tujuan pembelajaran secara jelas kepada mahasiswa, materi pembelajaran dapat diterima oleh semua mahasiswa, adanya interaksi yang bersifat terbuka, adanya tanggung jawab individu, interaksi sikap dan perilaku sosial yang positif, kelompok bersifat heterogen, adanya kepuasan dalam belajar, dan tindak lanjut.

\section{SIMPULAN}

Berdasarkan hasil penelitian dapat disimpulkan bahwa penerapan model pembelajaran jigsaw dapat meningkatkan motivasi dan hasil belajar mahasiswa penjas pada mata kuliah filsafat penjas dan olahraga.

\section{DAFTAR PUSTAKA}

Altun, S. (2015). The effect of cooperative learning on students' achievement and views on the science and technology course. International Electronic Journal of Elementary Education.

Budiawan, M. (2013). Pengaruh model 
Journal of Sport Education (JOPE), 2 (2) 2020 - 69

Yahya Eko Nopiyanto ${ }^{1}$, Septian Raibowo ${ }^{2}$

pembelajaran kooperatif tipe jigsaw dan motivasi belajar terhadap prestasi belajar ilmu fisiologi olahraga. JPI (Jurnal Pendidikan https://doi.org/10.23887/jpiundiksha.v2i1.1410

Gull, F., \& Shehzad, S. (2015). Effects of Cooperative Learning on Students' Academic Achievement. Journal of Education and Learning (EduLearn). https://doi.org/10.11591/edulearn.v9i3.2 071

Hossain, A., \& Tarmizi, R. A. (2013). Effects of Cooperative Learning on Students' Achievement and Attitudes in Secondary Mathematics. Procedia - Social and Behavioral Sciences. https://doi.org/10.1016/j.sbspro.2013.09. 222
Lie, A. (2010). Cooperative Learning. Jakarta: Grasindo.

Sardiman. (2012). Interaksi dan motivasi belajar mengajar. Jakarta: Grafindo Persada.

Susanto. (2015). Teori belajar dan pembelajaran. Jakarta: Prenada Media Group.

Thomas, P., \& Setiaji, K. (2014). E-learning dengan pendekatan kooperatif tipe jigsaw untuk meningkatkan aktivitas dan hasil belajar mahasiswa. 9(1).

Tsay, M., \& Brady, M. (2010). A case study of cooperative learning and communication pedagogy: Does working in teams make a difference? Journal of the Scholarship of Teaching \& Learning. 